\section{PRODUÇÃO INDUZIDA DE ANTICORPOS IN VITRO: NOVO MÉTODO PARA O DIAGNÓSTICO DE INFECÇÃO PERINATAL PELO VÍRUS DA IMUNODEFICIÊNCIA HUMANA}

Tendo em vista a capacidade de células mononucleares (CM), de sangue periférico de indivíduos infectados pelo HIV, secretarem anticorpos espontaneamente in vitro, foi desenvolvido um novo método laboratorial de produção induzida de anticorpos anti-HIV-1 in vitro (IVIAP) a ser utilizado no diagnóstico de infecção perinatal. Empregaram-se, na padronização da IVIAP, CM de dois grupos: 33 adultos e 30 crianças infectados pelo HIV-1 e 16 adultos e 21 crianças sem dados epidemiológicos, HIV-1soronegativos. Para estimular a secreção de anticorpos in vitro foi usado antígeno bruto do HIV 1 adsorvido a placas de um kit comercial de ELISA e testadas várias concentrações de $\mathrm{CM}$ e diferentes tempos de cultura. Os anticorpos produzidos pela CM foram detectados na placa, por reação imunoenzimática, com os reagentes do próprio kit e as instruções do fabricante. Os resultados obtidos mostraram que não houve reação cruzada ou falsopositiva quando foram avaliadas $\mathrm{CM}$ do grupo controle HIV-1 soronegativo. No grupo de indivíduos infectados foi possivel determinar como sendo $10^{5} \mathrm{CM}$ por orifício da placa e $24 \mathrm{~h}$ de cultura a condição ideal para resultar uma IVIAP positiva. Para comparar a eficiência da IVIAP em relação a outras técnicas de secreção de anticorpos in vitro, foram utilizadas $\mathrm{CM}$ de 19 adultos e 13 crianças infectados pelo HIV-1 na IVIAP, IVAP eELISPOT, demonstrando que a IVIAP foi mais sensível para detectar infecção pelo HIV, nos casos pediátricos. De um grupo de 57 crianças, acompanhado clínica e laboratorialmente por um período médio de 18 meses, foi possível comparar os resultados obtidos na IVIAP com os da sorologia para o HIV, antigenemia p24 e reação em cadeia de polimerase (PCR). Observaram-se resultados falso-negativos nos casos de hipogamaglobulinemia. A IVIAP se mostrou mais sensível para detectar infecção pelo

\author{
IN VITRO-INDUCED ANTIBODY \\ PRODUCTION: A NEW METHOD \\ FOR DIAGNOSIS OF PERINATAL \\ INFECTION BY HUMAN \\ IMMUNODEFICIENCY VIRUS
}

Using the ability of peripheral blood mononuclear cells (PBMC) of HIV-1 infected patients to secrete spontaneously specific-antibodies in vitro, it was attempted to develop a new laboratory method of in vitro-induced antibody production (IVIAP) to be used in the diagnosis of perinatal infection. PBMC obtained from 33 adults and 30 children infected with HIV-1, and 16 adults and 21 children who were HIV-1 seronegative and asymptomatic, were used to standardize the IVIAP. Disrupted inactivated whole virus adsorbed onto commercial ELISA kit plates was used to stimulate antibody secretion. PBMC were incubated on the plates at different concentrations and for different periods of time. The secreted antibodies were detected on the plates using the reagents and the immunoenzimatic assay as recommended by the manufacturer. The results obtained showed no cross-reactivity or false-positivity when PBMC from HIV-1 seronegative individuals were analyzed. Among the patients, a positive IVIAP was standardized in $24 \mathrm{~h}$ of culture using $10^{5} \mathrm{PBMC}$ per plate well. In order to compare the IVIAP with other techniques of in vitro antibody production, PBMC obtained from 19 adults and 13 children infected with HIV-1 were used in IVIAP, IVAP and ELISPOT tests. According to the results obtained, the IVIAP showed more sensitivity in detecting HIV-1 infected children than the IVAP and ELISPOT assays. Fifty-seven children were analyzed by clinical examination and laboratory tests for a median period of 18 months, when the results obtained from IVIAP were compared with those obtained from HIV serology, p24 antigenaemia and polymerase chain reaction (PCR). False-positive results were observed in children aged under 2 months, and false-negative results in cases of hypogammaglobulinemia. The IVIAP proved to be more sensitive in detecting HIV infection than 
Resumo de Tese. Caterino-de-Araujo A. Produção induzida de anticorpos in vitro: novo método para o diagnóstico de infecção perinatal pelo vírus da imunodeficiência humana. Revista da Sociedade Brasileira de Medicina Tropical 27:105-106, abr-jun, 1994.

HIV que a sorologia e a antigenemia p24. Houve concordância entre os resultados obtidos na IVIAP e na PCR. Neste estudo, a IVIAP apresentou $91 \%$ de sensibilidade e $96 \%$ de especificidade. Concluindo: foi possível desenvolver um novo método laboratorial para o diagnóstico de infecção perinatal pelo HIV - IVIAP - sendo sensível, específico, rápido, prático e de baixo custo, podendo ser usado com crianças de mais de dois meses de idade. serology and $\mathrm{p} 24$ antigenaemia. The results obtained by the IVIAP and PCR techniques were concordant. The IVIAP showed $91 \%$ sensibility and $96 \%$ specificity. In conclusion, it was possible to develop a new method to detect in vitro-induced antibody production (IVIAP) that proved to be sensitive, specific, rapid, practical and of low cost, an extremely valuable and useful tool for the diagnosis of HIV infection in infants aged at least 2 months.

Adele Caterino-de-Araujo

Tese apresentada ao Instituto de Ciências Biomédicas da

Universidade de São Paulo para

obtenção do título de Doutor.

São Paulo, SP, Brasil, 1993. 